\title{
Treatment of classic phenylketonuria in Poland in the years 2009-2015 based on the database of the Polish National Health Fund
}

\author{
Leczenie fenyloketonurii w Polsce w latach 2009-2015 na podstawie bazy danych
}

Narodowego Funduszu Zdrowia

\author{
${ }^{1}$ Agnieszka Szypowska, ${ }^{2}$ Edward Franek, ${ }^{3}$ Władysław J. Grzeszczak, ${ }^{4}$ Mariusz Zięba, \\ ${ }^{5}$ Winicjusz Filipow, ${ }^{4}$ Paweł Kabicz, ${ }^{4}$ Barbara Więckowska, ${ }^{6}$ Jolanta Sykut-Cegielska, ${ }^{6}$ Joanna Taybert
}

${ }^{1}$ Department of Pediatrics, Medical University of Warsaw, Warsaw, Poland

${ }^{2}$ Clinical Department of Internal Diseases, Endocrinology and Diabetology, The Central Clinical Hospital of the Ministry of the Interior and Administration, Warsaw, Poland

${ }^{3}$ Department of Internal Medicine, Diabetology and Nephrology, Medical University of Silesia, Katowice, Poland

${ }^{4}$ Department of Analysis and Strategy, Ministry of Health, Poland

${ }^{5}$ Research and Development Department at Diabetica company, Diabetica company, Polska

${ }^{6}$ Department of Inborn Errors of Metabolism and Paediatrics, Institute of Mother and Child, Poland

\begin{abstract}
Introduction: To avoid the risk of intellectual disabilities, newborns in Poland are screened for phenylketonuria and are recommended to start a life-long phenylalanine-restricted diet shortly after birth. The aim of this paper is to evaluate the health care for patients with classical phenylketonuria in Poland.

Material and methods: We reviewed the National Health Fund's reporting data concerning information on healthcare services for patients with classical phenylketonuria (PKU), which were reported to the payer by the healthcare service providers between 2009 and 2015. The analysis was prepared within the framework of mapping the health care needs of patients with metabolic diseases published in December 2016 (http://www.mapypotrzebzdrowotnych.mz.gov.pl/).

Results: A total of 2706 patients with PKU (including 1180 children) were registered in the healthcare system in the period covered. The estimated national prevalence of PKU was 1 per 7758 live births. Paediatric patients up to 12 moths of age accounted for over $40 \%$ of all visits to outpatient clinics. Patients over 28 years of age accounted for only $1 \%$ of all PKU patients receiving specialist outpatient care. There were twice as many clinics providing health care to children than to adults. The majority of adult patients received healthcare from the same providers as children. Sixty-nine percent of adults and $64 \%$ of children were treated in the two largest outpatient centres. There were 12 deaths, with a median age of 63 years. The working-age adults accounted for $50 \%$ of the deaths. Conclusions: Adult patients with PKU do not receive sufficient healthcare. The discontinuation of healthcare by adults with PKU can result from the lack of an adequate transition process from paediatric to adult care.
\end{abstract}

Key words:

phenylketonuria, healthcare, management.

\section{Streszczenie}

Wprowadzenie: Aby uniknąć ryzyka niepełnosprawności intelektualnej, noworodki w Polsce są poddawane badaniom przesiewowym w kierunku fenyloketonurii i wkrótce po urodzeniu zaleca się rozpoczęcie diety ograniczającej fenyloalaninę przez całe życie.

Cel pracy: Ocena opieki zdrowotnej chorych na klasyczną fenyloketonurię (PKU) w Polsce.

Materiał i metody: Przeanalizowano dane sprawozdawcze Narodowego Funduszu Zdrowia dotyczące informacji o świadczeniach opieki zdrowotnej dla chorych na PKU, których świadczeniodawcy zostali zgłoszeni płatnikowi w okresie od 2009 do 2015 roku. Analiza została przygotowana w ramach mapowania potrzeb zdrowotnych pacjentów z chorobami metabolicznymi opublikowanego w grudniu 2016 r. (http://www.mapypotrzebzdrowotnych.mz.gov.pl/).

Wyniki: W omawianym okresie w systemie opieki zdrowotnej zarejestrowano łącznie 2706 pacjentów z PKU (w tym 1180 dzieci). Szacunkowa częstość występowania PKU w kraju wynosiła 1 na 7758 żywych urodzeń. Wizyty realizowane przez dzieci do 12. mie- 
siąca życia stanowiły ponad 40\% wszystkich wizyt w przychodniach. Pacjenci w wieku powyżej 28 lat stanowili tylko $1 \%$ wszystkich chorych na PKU leczonych ambulatoryjnie specjalistycznie. Specjalistycznych przychodni dla dzieci było 2 razy więcej niż przychodni dla dorosłych. Większość dorosłych pacjentów otrzymała opiekę zdrowotną w przychodniach pediatrycznych. W dwóch największych leczono 69\% dorosłych i 64\% dzieci. Stwierdzono 12 zgonów, mediana wieku pacjentów wynosiła 63 lata. Dorośli w wieku produkcyjnym odpowiadali za $50 \%$ zgonów.

Wnioski: Dorośli chorzy na PKU nie otrzymują wystarczającej opieki zdrowotnej. Przerwanie opieki zdrowotnej przez dorosłych z PKU wynika z braku odpowiedniego procesu przejścia z opieki pediatrycznej do opieki dla dorosłych.

\section{Słowa kluczowe:}

fenyloketonuria, opieka zdrowotna, zarządzanie.

\section{Introduction}

Phenylketonuria (PKU) is an autosomal recessive inborn error of phenylalanine (Phe) metabolism. The estimated national prevalence of classic phenylketonuria (PKU) in Poland is 1 per 7000 live births [1]. This translates into about 50-60 live births with PKU per year. The PKU screening of newborns in Poland is funded by the Ministry of Health as part of the preventive healthcare system. The screening tests are mandatory for all newborns irrespective of their insurance status [2].

High Phe levels in PKU patients are toxic to the central nervous system, leading to neurocognitive deficits and intellectual disability. Using Phe-free medical foods and avoiding highprotein products successfully lowers blood Phe levels in most individuals with PKU [3]. Some patients benefit from the use of a synthetic form of tetrahydrobiopterin $(\mathrm{BH} 4)$ - the natural cofactor for the PAH enzyme (sapropterin dihydrochloride) [4]. A phenylalanine-restricted diet soon after birth with regular monitoring of blood Phe levels prevents serious consequences of the disease, which are observed in untreated PKU patients $[5,6]$.

Pursuant to the treatment guidelines of the American College of Medical Genetics and Genomics (ACMG), the clinical treatment goal for individuals with PKU is to maintain blood Phe within the range of $(120-360 \mu \mathrm{mol} / \mathrm{l})$ [7]. The same range is recommended in the latest European guidelines for PKU patients aged up to 12 years as well as in women before and during pregnancy. After the age of 12 years, patients with PKU should aim for blood Phe levels of 120-600 $\mu \mathrm{mol} / \mathrm{l}$ [8]. Before introducing the Phe-restricted diet, severe intellectual disabilities were the main and most frequent consequence of the disease. The duration of dietary treatment aroused a great deal of controversy due to the conviction that elevated Phe levels should not have adverse effects on the fully developed brain. Therefore, in the 1980s some medical centres approved discontinuation of the diet. Currently, a phenylalanine-restricted diet is recommended for life $[9,10]$. It is also equally important to take special care with women during childbearing years and in pregnancy. Prolonged elevated Phe levels, particularly during embryogenesis, cause birth defects (intrauterine growth retardation, microcephaly, neurocognitive impairment, and congenital heart disease) known as maternal phenylketonuria syndrome $[11,12]$. Moreover, certain neuropsychological and behavioural deficits such as anxiety, depression, or executive function deficit can occur despite strict adherence to a Pherestricted diet [13, 14]. Unfortunately, newborn PKU screening tests are still not available in certain regions of Europe, and the treatment of PKU patients is falling behind the internationally established standards of care in many aspects $[15,16]$.

The authors emphasise the key role of the healthcare system in achieving optimal treatment outcomes. Patients with PKU require multidisciplinary care approach including access to paediatricians specialising in metabolic diseases, nutritionists and psychologists as well to Phe-free medical foods and laboratories. Additionally, the families of PKU patients are in need of genetic counselling. The transition of patients from paediatric to adult care facilitates further healthcare processes and may prevent discontinuation of a phenylalanine-restricted diet in adult life $[17,18]$

The aim of this paper is to evaluate the current healthcare status of PKU patients in Poland based on the data provided to the Polish National Health Fund by healthcare service providers.

\section{Material and methods}

The health insurance in Poland is financed from public funds by a single entity: the National Health Fund (NFZ). The insurance covers all children regardless of the insurance status of their parents. The National Health Fund (NFZ) acts as the payer, financing healthcare services reported by respective healthcare service providers under contracts for the provision of health services for patients insured by the fund. The present study investigates the National Heath Fund's reporting data on healthcare services that were provided to the payer (the $\mathrm{Na}$ tional Health Fund) by different healthcare service providers in Poland in the period between 2009 and 2015.

The authors analysed the body of data on healthcare services provided to adults and children assigned with code E70.0 according to the International Classification of Diseases and Related Health Problems (ICD-10). The data for each individual patient was coded in the National Health Fund's database under a unique patient identifier.

To measure the registered incidence of PKU based on the information available in the database of the National Health Fund, the authors analysed the data for patients who were registered in the public healthcare system since 2009. The regis- 


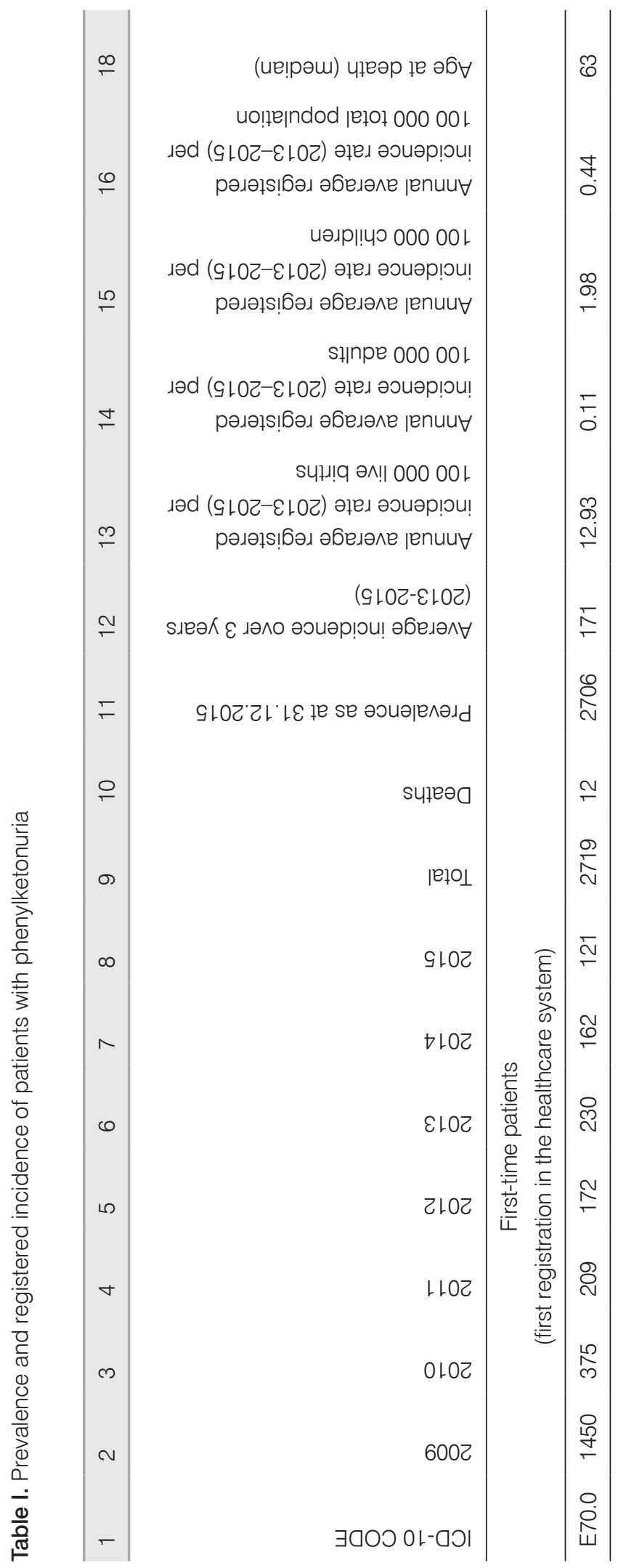

tered incidence was defined as the number of new patients diagnosed with phenylketonuria (E70.0) appearing in the public healthcare system based on the data from the period between 2009 and 2015.

Data in the National Health Fund database were collected since 2009. Some of the cases reported in previous years were classified as cases from 2009; therefore, the numbers for this year are usually overstated. For this reason, when calculating the average incidence, the ages of patients were based on data from 2013-2015.

Patients appearing in NFZ's reporting system in this period were regarded as new patients (first-time patients) provided that they had been diagnosed with PKU for the first time in the period covered. The registered prevalence was defined as the incidence of PKU reported for the first time in the National Health Fund's database per 100,000 patients. The data that were used to measure the registered prevalence (i.e. new births, number of adults and children) were obtained from the Central Statistical Office (GUS).

To reduce the risk of error due to the change of the original diagnosis in the healthcare system, the treatment history of each patient was reviewed starting from the date of entry in the system, and the ICD code was overwritten if such a change was identified.

The data on inpatient and outpatient care obtained from the public healthcare system was analysed separately for adults and children. The analyses covered adults aged 18 years and above, children under 18 years of age, and neonatals classified as "newborns" based on homogeneous patient groups (JGP code, Homogeneous Groups of Patients N20-N34). The age at diagnosis was calculated based on the average age of patients in 2013-2015. The average age at death for patients who died in the period under investigation is presented in the last column of Table I.

The analysis was prepared as part of the project of mapping the health needs of patients with metabolic diseases published in December 2016 (http://www.mapypotrzebzdrowotnych.mz.gov.pl/).

The statistical analysis was conducted using R Studio software, version 1.0.136. The graphs presented in this publication were plotted using RStudio's "ggplot2" library for visualisation of data version 2.1.0, and Microsoft Excel 2013. Some of the graphs use logarithmic scale to more clearly present the scale of a given phenomenon.

\section{Results}

According to the data available in the database of the National Health Fund, the registered incidence rate of PKU was 12/9/100,000 (1: 7758) live births, 2.0/100,000 children, $0.1 / 100,000$ adults, and $0.4 / 100,000$ population (Table I). All children were diagnosed with PKU within the 


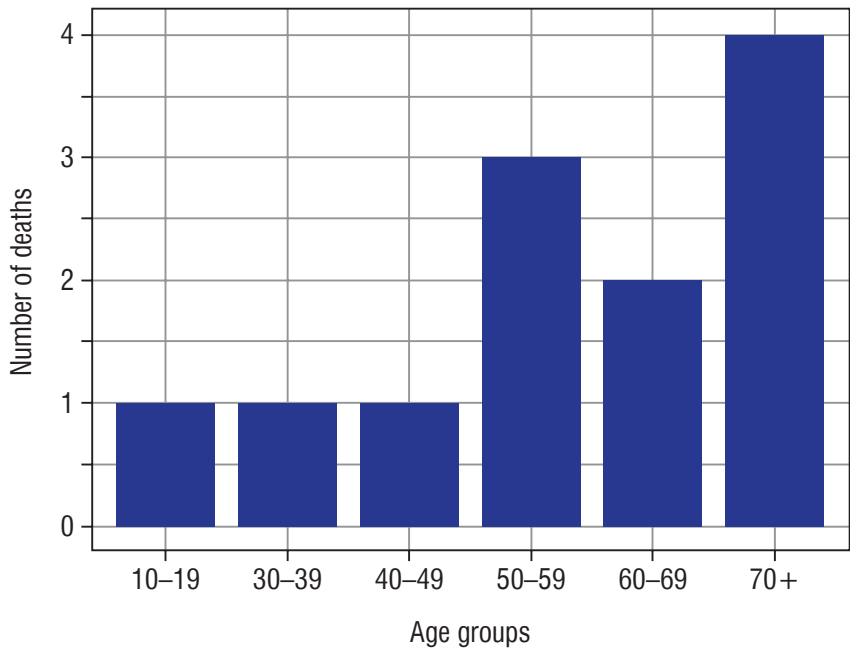

Figure 1. Deaths of patients with classical phenylketonuria (E70-0) by age

first few weeks of life and were put on Phe-restricted diet soon after the diagnosis. A total of 2706 patients with PKU were recorded in the NFZ's system as at 31 December 2015. Between 2009 and 2015 there were 12 reported PKU deaths with the mean age of 63 years. Six of the patients who died were between 10 and 59 years of age (Figure 1).

About $80 \%$ of all in-patients were children in their first 12 months of life. After the second year of life, the frequency of hospitalisations for patients diagnosed with PKU for the first time was close to zero. The children were mainly admitted to paediatric and gastroenterological wards (85\% and $10 \%$, respectively). Only six patients with first-time PKU diagnosis were over 18 years of age; all six patients $(n=6)$ were admitted to paediatric wards.

Between 2009 and 2015, 1180 children were registered in outpatient clinics. Over $40 \%$ of all outpatients were infants within the first 12 months of life. There was a sharp decline in the number of outpatient visits for patients of about 30 years of age. The outpatient visit rate for patients over 50 was nearly zero (Figure 2). Patients over 28 years accounted for only $1 \%$ of all PKU patients reported to the National Health Fund by healthcare service providers. A total of 551 outpatient care adults over 18 years old accounted for 2281 visits. 97\% of adults and children received treatment in metabolic care clinics. The analysis of healthcare service providers that reported at least 10 visits by at least two patients demonstrated that there were twice as many clinics for children as for adults (Figure 3). Most of the adult patients were treated by the same healthcare service providers as children. The two largest healthcare centres - The Institute of Mother and Child and the Regional Specialist Hospital in Wroclaw - accounted for the highest number of treated children $(n=751)$ and adults $(n=381)$. Both centres

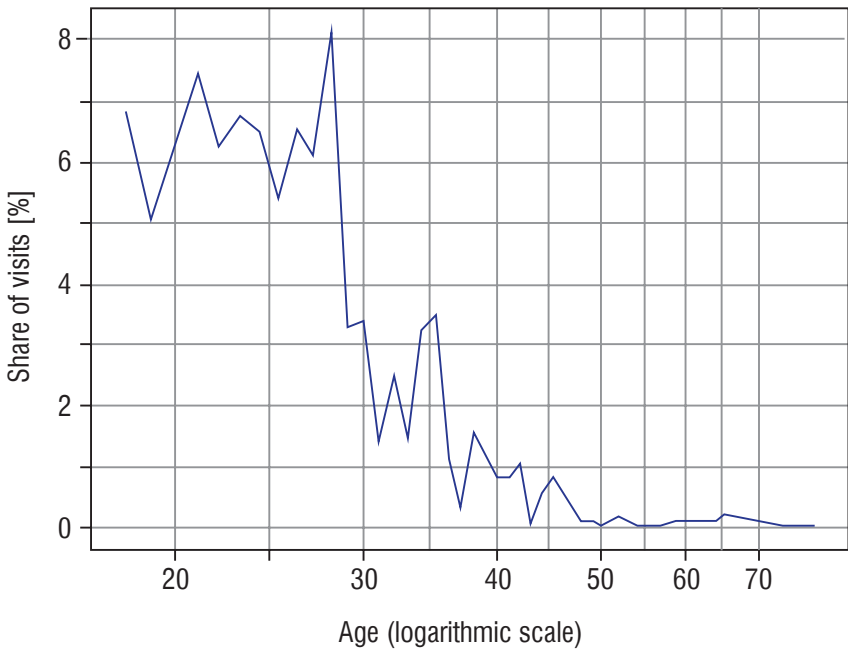

Figure 2. Structure of advice to adults with phenylketonuria (E70-0) in specialist outpatient care

also reported the most visits for adults and children $(n=1957$ and $n=7676$, respectively).

\section{Discussion}

We present herein the results of the first study evaluating the incidence and treatment of patients with phenylketonuria based on information from the database of the National Health Fund covering the period from 2009 to 2015. We estimated the registered incidence of PKU at 1 per 7758 live births. The incidence results are consistent with the previously reported prevalence in the Polish population, which had been estimated at about 1 per 7000 live births, based on the results of national newborn screening tests. PKU screening is carried out as part of the national screening program for newborn babies [19]. The program was launched almost 30 years ago and is coordinated by the Institute of Mother and Child in Warsaw.

A total of 2706 patients with PKU were recorded in the database of the National Health Fund between 2009 and 2015. Infants in the first 12 months of life accounted for the highest number of hospitalisations and outpatient visits, which shows the good organisation of the healthcare process for infants and is consistent with the current treatment guidelines. Ninetyseven percent of adults and children in the study population remained under the care of a metabolic clinic. There was a substantial decline in the number of adults remaining under the care of an outpatient clinic compared to paediatric patients. The number of healthcare service providers which reported at least 10 visits by at least two patients was almost twice as low for adults as for children. Moreover, most of the adult patients visited the same healthcare service providers as children, with 

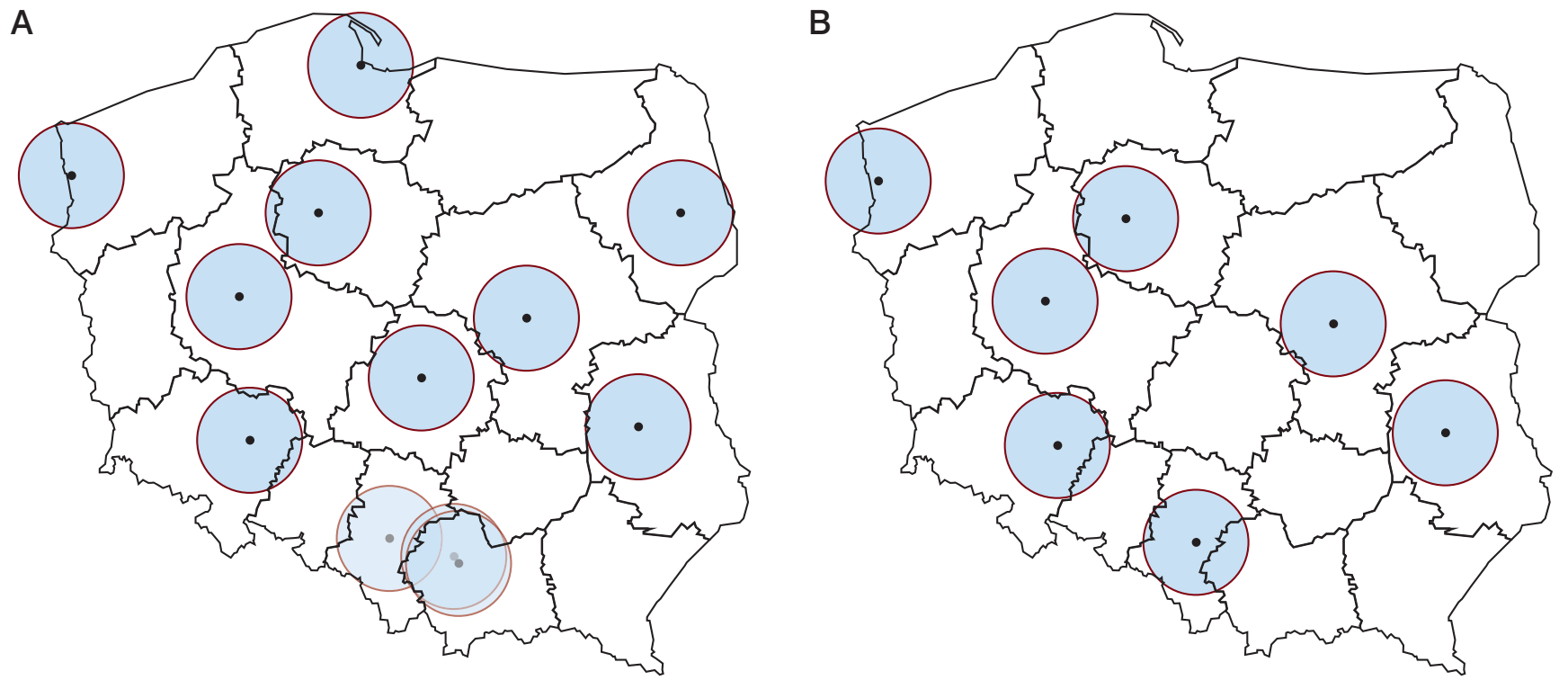

Figure 3. Dot maps with locations of healthcare service providers which provided at lest 10 recommendations to at least 2 patients with phenylketonuria. A - children; B - adults. Each location was marked with circle with $50 \mathrm{~km}$ radius

two large outpatient departments accounting for the management of almost two thirds of all adult PKU patients.

The number of metabolic care centres defined as healthcare clinics dedicated to adult patients with inborn errors of metabolism, including PKU, is insufficient in Poland. This problem exists in many countries where most clinics in paediatric hospitals do not have contracts with the National Heath Fund for the treatment of adult patients [20]. The majority of paediatric outpatient clinics in Poland usually have contracts with the NFZ providing for the treatment of children and adolescents under 18 years of age. Only a few clinics have signed contracts with the NFZ which ensure the provision of healthcare services for adult patients with phenylketonuria.

The transition of adult patients with phenylketonuria from paediatric to adult is not sufficiently addressed. There are several groups of adult patients with PKU with specific healthcare needs. These include individuals with neurocognitive disorders and intellectual disability, who were born before the introduction of screening tests and were therefore diagnosed in their adulthood. Another group comprises patients who had been covered by the screening program and later decided to discontinue the phenylalanine-restricted diet. Most of them have stopped attending outpatient visits. The third group are young adults on a continuous Phe-restricted diet, who prefer regular but sporadic follow-up outpatient appointments. The last and most important group comprises women of childbearing age. The proper treatment and strict adherence to medical recommendations before and during pregnancy guarantee a healthy baby. Mütze et al. reported that $81 \%$ of the transferred PKU patients from paediatric to adult care in the University Hospital
Leipzig, Germany still maintained contact with their adult care clinic. Moreover, $83 \%$ of the PKU adults were satisfied with the transition process. Uninterrupted metabolic treatment in a specialised paediatric and adult outpatient clinic was successful, leading to stable metabolic control, life satisfaction, and economical welfare comparable to the general population [21].

Depending on personal choice or previous recommendations, some adult patients decide to discontinue the treatment for PKU. According to a recent meta-analysis, a high Phe concentration is associated with increased prevalence of neuropsychiatric symptoms and executive functioning deficits in adults with PKU [22]. The authors support lifelong maintenance of low blood Phe and emphasise that barriers inherent to managing a chronic medical condition as well as those specific to PKU can play a role in the decision to discontinue treatment. A study by the National PKU Alliance (NPKUA) demonstrated that many PKU patients have problems maintaining blood Phe levels within the recommended range, and the capacity to control blood Phe has been shown to deteriorate with age. The study outcomes show that children ( $\leq 18$ years) were approximately three times more successful than adults in maintaining their blood Phe levels within the recommended clinical range. Moreover, individuals with blood Phe levels within the recommended range were more likely to visit a metabolic clinic than those with Phe levels outside the recommended range. These observations emphasise the role of healthcare centres providing treatment for adults with phenylketonuria with the help of qualified personnel (such as metabolic disease specialists, dieticians, and psychologists) in the long-term maintenance of low blood Phe levels. 
The limited number of PKU centres in Poland (compared to paediatric facilities) indicates insufficient outpatient healthcare for adults with phenylketonuria. This is likely to have caused the sharp decline in actively treated adult patients with PKU. It should also be noted that the need for ensuring access to metabolic clinics for adult patients is further justified by the growing number of PKU cases. About 50-60 new PKU patients in Poland are enrolled in the national newborn screening program annually, with a similar number of patients reaching adulthood at that time. The healthcare programs for adult patients with PKU are deficient also in other countries. In a study by Berry et al., about $71 \%$ of adult PKU patients aged $19-45$ years in the USA were not actively treated by a metabolic clinic [23]. According to the results of a survey evaluating diagnostic and management practices for patients with PKU in 19 countries of the Southern and Eastern European region, metabolic dieticians and specialised adult PKU clinics were lacking in $36 \%$ and $84 \%$ of centres, respectively. Other authors have also emphasised the lack of sufficient numbers of healthcare centres and PKU specialists in the EU $[24,25]$.

We recorded 12 deaths with the median age at death of 63 years. In a study of people with untreated phenylketonuria, the average age at death was 55.8 years [26]. The average age at death of our patients (treated and untreated patients with ICD-10 code E70.0) was higher for the treated population. However, $50 \%$ of the deaths were reported in the working-age group. It is not possible to determine the cause of the deaths with the data available.

There are some other therapeutic options in PKU besides a Phe-restricted diet. Unfortunately, none of them is available currently in Poland. Among them, sapropterin (i.e. BH4) is the first certified medication for PKU. It stimulates activity of the residual PAH enzyme and helps to transform Phe into tyrosine. The first FDA-approved enzyme substitution therapy addressed to adult patients with PKU is pegvaliase (PAL), which substitutes a PEGylated version of the enzyme Phe ammonia lyase for the deficient PAH enzyme. Recently a new variant (AvPAL) has been engineered in order to improve stability in the gastrointestinal tract. Also, a new substance called Phelimin has been introduced as monotherapy in PKU, which prevents Phe absorption from dietary proteins. Last, but not least, there are clinical trials in PKU concerning gene therapy as either gene transfer or gene editing administered directly to liver cells.
The advantage of our study is that it analyses all PKU cases reported with the National Health Fund in the years 2009-2015. However, the study is not without certain drawbacks, one of them being that it covers only patients registered in the healthcare system, without addressing the unregistered PKU cases. Twenty-two percent of the patients with disorders of aromatic amino-acid metabolism were assigned code E70 according to the International Classification of Diseases and Related Health Problems (ICD-10) - disorders of aromatic amino-acid metabolism, unspecified. Another disadvantage is the inability to verify the diagnosis within this patient group, which could have affect the number of patients in respective groups coded with an extension. The absence of code extensions could be due to miscoding or might reflect the failure to provide a specific diagnosis. Due to the absence of specific code extensions in the reporting data, one cannot rule out the possibility that some patients with classical phenylketonuria (E 70.0) are missing in the E70 coded group. Moreover, the study did not take account of some factors affecting the adherence to treatment recommendations (e.g. the cost of treatment) and did not address the cause of patient deaths.

\section{Conclusions}

With the introduction of the Polish newborn screening program, children with PKU are diagnosed and treated in metabolic clinics shortly after birth. However, there is no adequate healthcare program for adult patients with PKU. The discontinuation of active treatment by adults with PKU can be due to the absence of an optimal healthcare program addressing the transition from paediatric to adult care. In terms of a model of this transition, there is a similar problem in other countries inside and outside Europe. However, in some western European countries (such as Norway, the Netherlands, or Great Britain) beneficial solutions regarding the health care system for adult patients with PKU have been implemented. But such models could not be directly transferred to Poland, due to our specific official conditions and needs. Further studies evaluating the cost of treatment as well as the social and healthcare systems are therefore necessary to improve the healthcare services for adults with phenylketonuria. 
Szypowska A., Franek E., Grzeszczak W.J., Zięba M., Filipow W., Kabicz P., Więckowska B., Sykut-Cegielska J., Taybert J.

\section{References}

1. Giżewska M, MacDonald A, Bélanger-Quintana A, et al. Diagnostic and management practices for phenylketonuria in 19 countries of the South and Eastern European Region: survey results. Eur J Pediatr 2016; 175: 261-272. doi: 10.1007/s00431-015-2622-5

2. Jarochowicz S, Mazur A. Fenyloketonuria - choroba metaboliczna uwarunkowana genetycznie. Przegląd Medyczny Uniwersytetu Rzeszowskiego 2007; 1: 76-90.

3. Singh RH, Rohr F, Frazier D, et al. Recommendations for the nutrition management of phenylalanine hydroxylase deficiency. Genet Med 2014; 16: 121-131. doi: 10.1038/gim.2013.179

4. Longo N, Arnold GL, Pridjian G, et al. Long-term safety and efficacy of sapropterin: the PKUDOS registry experience. Mol Genet Metab 2015; 114: 557-563. doi: 10.1016/j.ymgme.2015.02.003

5. Żółkowska J. Dietetic treatment in classical phenylketonuria. Standardy Medyczne/Pediatria 2014; 11: 555-564.

6. Hagedorn TS, van Berkel P, Hammerschmidt G, et al. Requirements for a minimum standard of care for phenylketonuria: the patients' perspective. Orphanet J Rare Dis 2013; 8: 191. doi: 10. 1186/1750-1172-8-191

7. Vockley J, Andersson HC, Antshel KM, et al. Phenylalanine hydroxylase deficiency: Diagnosis and management guideline. Genet Med 2014; 16: 188-200. doi: 10.1038/gim.2013.157.

8. van Wegberg AMJ, MacDonald A, Ahring K, et al. The complete European guidelines on phenylketonuria: diagnosis and treatment. Orphanet J Rare Dis 2017; 12: 162. doi: 10.1186/s13023017-0685-2

9. Koch R, Burton B, Hoganson G, et al. Phenylketonuria in adulthood: a collaborative study. J Inherit Metab Dis 2002; 25: 333-346.

10. Lindegren ML, Krishnaswami S, Fonnesbeck C, et al. Adjuvant Treatment for Phenylketonuria (PKU). Comparative Effectiveness Review No. 56. (Prepared by the Vanderbilt Evidence-based Practice Center under Contract No. HHSA 290-2007-10065-I.) AHRQ Publication No. 12- EHC035-EF. Rockville, MD: Agency for Healthcare Research and Quality; February 2012. Available at: www.effectivehealthcare.ahrq.gov/reports/final.cfm.

11. Moseley KM, Skrabal J, Yano S, Koch R. Sapropterin dihydrochloride (6RBH4) and maternal phenylketonuria two case studies. Infan Child Adoles Nutr 2009; 5: 262-266. doi: https://doi. org/10.1177/1941406409344097

12. Didycz B, Domagała B, Pietrzyk JJ. The maternal phenylketonuria syndrom - still current problem. Przegląd Lekarski 2009; 66: 4-10.

13. Gentile JK, Ten Hoedt AE, Bosch AM, Psychosocial aspects of PKU: hidden disabilities - a review. Mol Genet Metab 2010; 99
Suppl 1: S64-S67. doi: 10.1023/a:1020158631102. doi: 10.1016/j. ymgme.2009.10.183

14. Brown CS, Lichter-Konecki U. Phenylketonuria (PKU): A problem solved? Mol Genet Metab Rep 2015; 29: 8-12. doi: 10.1016/j. ymgmr.2015.12.004

15. Zerjav Tansek M, Groselj U, Angelkova N, et al. Phenylketonuria screening and management in southeastern Europe - survey results from 11 countries. Orphanet J Rare Dis 2015; 10: 68. doi: 10.1186/s13023-015-0283-0

16. Groselj U, Tansek MZ, Smon A, et al. Newborn screening in southeastern Europe. Mol Genet Metab 2014; 113: 42-45. doi: 10. 1016/j.ymgme.2014.07.020

17. Camp KM, Parisi MA, Acosta PB, et al. Phenylketonuria Scientific Review Conference: state of the science and future research needs. Mol Genet Metab 2014; 112: 87-122. doi: 10.1016/j.ymgme.2014.02.013

18. Mütze U, Roth A, Weigel JF, et al. Transition of young adults with phenylketonuria from pediatric to adult care. J Inherit Metab Dis 2011; 34: 701-709. doi: 10.1007/s10545-011-9284-x

19. http://www.mz.gov.pl/zdrowie-i-profilaktyka/programy-zdrowotne/wykaz-programow/program-bada-przesiewowych-noworodkow-w-polsce-na-lata-2009-2014/.

20. Burton BK, Leviton L. Reaching out to the lost generation of adults with early treated phenylketonuria (PKU). Mol Genet Metab 2010; 101: 146-148. doi: 10.1016/j.ymgme.2010.06.006

21. Mütze $U$, Thiele AG, Baerwald $C$, et al. Ten years of specialized adult care for phenylketonuria - a single-centre experience. Orphanet. J Rare Dis 2016; 11: 27. doi: 10.1186/s13023-016-0410-6

22. Bilder DA, Noel JK, Baker ER, et al. Systematic review and metaanalysis of neuropsychiatric symptoms and executive functioning in adults with phenylketonuria. Dev Neuropsychol 2016; 41: 245-260. doi: 10.1080/87565641.2016.1243109

23. Berry SA, Brown C, Grant M, et al. Newborn screening 50 years later: access issues faced by adults with PKU. Genet Med 2013; 15: 591-599. doi: 10.1038/gim.2013.10

24. Ahring K, Bélanger-Quintana A, Dokoupil K, et al. Dietary management practices in phenylketonuria across European centres. Clin Nutr 2009; 28: 231-236. doi: 10.1016/j.clnu.2009.03.004

25. European Society for Phenylketonuria and Allied Disorders: PKU: Closing the Gaps in Care. An ESPKU benchmark report on the management of phenylketonuria within EU healthcare economies. http://www.espku.org/en/pku-in-europe.

26. Jancar J. Increased life expectancy in people with untreated phenylketonuria. J Intellect Disabil Res 1998; 42: 97-99. doi: 10. 1046/j.1365-2788.1998.00067.x 